\title{
A Cell Surface Receptor Complex for Fibrillar $\beta$-Amyloid Mediates Microglial Activation
}

\author{
Maria E. Bamberger, ${ }^{1,2}$ Meera E. Harris, ${ }^{2}$ Douglas R. McDonald, ${ }^{3}$ Jens Husemann, ${ }^{4}$ and Gary E. Landreth ${ }^{2}$ \\ Alzheimer Research Laboratory, ${ }^{1}$ Program in Cell Biology and ${ }^{2}$ Departments of Neurosciences and Neurology, Case Western Reserve University School of \\ Medicine, Cleveland, Ohio 44106, ${ }^{3}$ Department of Immunology, Children's Hospital, Boston, Massachusetts 02115, and ${ }^{4}$ Department of Physiology and \\ Cellular Biophysics, Columbia University College of Physicians and Surgeons, New York, New York 10032
}

\begin{abstract}
Senile plaques found in the Alzheimer's disease brain are foci of local inflammatory reactions mediated by plaque-associated microglia. The interaction of microglia with compacted deposits of $\beta$-amyloid $(\mathrm{A} \beta)$ fibrils results in the stimulation of intracellular Tyr kinasebased signaling cascades and cellular activation, leading to the secretion of proinflammatory molecules. This study identifies a cell surface receptor complex that mediates the binding of microglia to $\mathrm{A} \beta$ fibrils and the subsequent activation of intracellular signaling pathways leading to a proinflammatory response. The receptor complex includes the B-class scavenger receptor CD36, the integrinassociated protein/CD47, and the $\alpha_{6} \beta_{1}$-integrin. Antagonists of scavenger receptors, $\mathrm{CD} 36, \mathrm{CD} 47$, and $\alpha_{6} \beta_{1}$ inhibited the adhesion of THP-1 monocytes to A $\beta$ fibrils. In addition, peptide competitors of A $\beta$ fibril interactions with CD36, scavenger receptors, CD47, and the $\alpha_{6} \beta_{1}$-integrin inhibited $\mathrm{A} \beta$ stimulation of Tyr kinase-based signaling cascades in both THP-1 monocytes and murine microglia as well as interleukin $1 \beta$ production. A scavenger receptor antagonist and antibodies specific for $\mathrm{CD} 36$ and the $\beta_{1}$-integrin subunit also inhibited the $\mathrm{A} \beta$-stimulated generation of reactive oxygen species. Importantly, the principal components of this receptor complex are shared with those for other fibrillar proteins and thus represent general elements through which myeloid lineage cells recognize complex fibrillar proteins. Identification of the cell surface molecules that interact with $\mathrm{A} \beta$ fibrils and mediate their activation of intracellular signaling cascades represents a potential intervention point in the treatment of Alzheimer's disease.
\end{abstract}

Key words: Alzheimer's disease; $\beta$-amyloid; $\alpha_{6} \beta_{1}$-integrin; CD36; CD47; microglia; THP-1 monocytes; scavenger receptor; signal transduction; receptors; Tyr kinase

\section{Introduction}

The contribution of an inflammatory component to the pathogenesis of Alzheimer's disease (AD) has been well documented (Akiyama et al., 2000). Microglia are the principal immune effector cells in the brain and undergo a conversion into a reactive proinflammatory phenotype after their association with fibrillar $\beta$-amyloid $(\mathrm{A} \beta)$ deposits comprising the senile plaques in the $\mathrm{AD}$ brain. Epidemiological studies have demonstrated the decreased incidence and severity of $\mathrm{AD}$ in patient populations treated with nonsteroidal anti-inflammatory drugs (Rich et al., 1995; Breitner, 1996; Stewart et al., 1997; in't Veld et al., 2001), which were correlated with a $65 \%$ reduction in plaque-associated reactive microglia (Mackenzie and Munoz, 1998). These data support a role for microglia in the pathophysiology of $\mathrm{AD}$ and as a target of anti-inflammatory therapy.

The interaction of microglia with fibrillar forms of $\mathrm{A} \beta$ peptides initiates cellular activation, as evidenced by the enhanced expression of immune cell markers by these cells, including CD45, major histocompatibility complex class I and II antigens,

\footnotetext{
Received Aug. 8, 2002; revised Jan. 14, 2003; accepted Jan 14, 2003.

This work was supported by National Institutes of Health Grants AG 16740 and AG 08012 and Training Grant GM 08056-18 (M.E.B.). J.H. was was supported by Columbia University Alzheimer's Disease Research Center Pilot Grant Award AG 08702 and the Alzheimer's Association. We thank the Blanchett Hooker Rockefeller Foundation and the Coins for Alzheimer's Research Trust Fund of Rotary International for generous support of our work. We thank Dr. Colin Combs for assistance and helpful comments on this manuscript and Dr. Frieda Pearce and Dr. Mark Kindy for providing us with reagents.

Correspondence should be addressed to Dr. Gary Landreth, Alzheimer Research Laboratory, E504, Case Western Reserve University School of Medicine, 10900 Euclid Avenue, Cleveland, 0H 44106. E-mail: gel2@po.cwru.edu. Copyright $\odot 2003$ Society for Neuroscience $\quad 0270-6474 / 03 / 232665-10 \$ 15.00 / 0$
}

Fc $\gamma$ receptors, and complement receptors 3 and 4 (Akiyama et al., 2000). The plaque-associated microglia also exhibit increased levels of intracellular phospho-Tyr staining (Wood and Zinsmeister, 1991), which is a consequence of the activation of Tyr kinase-based signaling pathways on exposure of the cells to $\mathrm{A} \beta$ fibrils (McDonald et al., 1997, 1998; Combs et al., 1999). Significantly, these $A \beta$-stimulated microglial signaling events lead to the production and secretion of a broad range of proinflammatory molecules and neurotoxic factors that contribute to the sustained inflammatory response and neuronal loss observed in $\mathrm{AD}$ (Combs et al., 2000, 2001; Yates et al., 2000).

There has been considerable interest in the identity of the cell surface receptor(s) that mediates microglial activation on interaction with $\mathrm{A} \beta$ fibrils. A number of receptors have been reported to bind $\mathrm{A} \beta$, namely scavenger receptor class A (SR-A; El Khoury et al., 1996; Paresce et al., 1996), SR-B1 (Husemann et al., 2001), the neuronal $\alpha 7$ nicotinic acetylcholine receptor (Dineley et al., 2001; Pettit et al., 2001), the receptor for advanced glycation end products (RAGE; Yan et al., 1996), the serpin enzyme complex (Boland et al., 1996), the formyl peptide chemotactic receptor (FPR; Lorton, 1997; Le et al., 2001), heparan sulfate proteoglycans (Giulian et al., 1998; Scharnagl et al., 1999), and the $\alpha_{5} \beta_{1}$-integrin (Matter et al., 1998). However, only SR-A and RAGE have been shown to interact with fibrillar forms of $A \beta$, and neither of these receptors is linked to activation of intracellular signaling cascades leading to a proinflammatory response. Recently, while this work was in progress, the B class scavenger receptor CD36 was also shown to act as a receptor for fibrillar A $\beta$ (Coraci et al., 2002; Moore et al., 2002). 
Our approach to the identification of putative $A \beta$ receptors arose from the recognition that myeloid lineage cells use multiple cell surface receptors to bind fibrillar proteins, and the assembly of ensembles of receptors is necessary for cellular activation (Ishibashi et al., 1994; Bornstein, 1995; Wong et al., 1996). We evaluated the involvement of a number of such receptors by monitoring their ability to induce intracellular signaling events and generation of proinflammatory molecules such as interleukin $1 \beta$ (IL-1 $\beta$ ) and reactive oxygen species (ROS). We report the identification of a multireceptor complex comprising the B-class scavenger receptor CD36, $\alpha_{6} \beta_{1}$-integrin, and the integrinassociated protein CD47. This complex mediates activation of microglia and other myeloid cells (e.g., THP-1 monocytes) on interaction with fibrillar $A \beta$ peptides.

\section{Materials and Methods}

Materials. The anti- $\beta_{1}$-integrin antibody Lia1/2 used for intracellular signaling assays was from Immunotech (Marseille, France). The $\beta_{1}$ integrin antibody used for adhesion assays and all $\alpha$ subunit integrin antibodies were from Chemicon (Temecula, CA). Anti- $\beta_{2}$-integrin antibody was from Roche Molecular Biochemicals (Indianapolis, IN). The anti-Fyn JD3 antibody was from Dr. S. Brady-Kalnay (Case Western Reserve University). The glutathione S-transferase (GST)-CD36-(93120) peptide was a gift from Dr. S. Frieda Pearce (Cornell University, Ithaca, NY). The anti-CD36 monoclonal antibody OKM5 was from Ortho-Clinical Diagnostics (Raritan, NJ). Mouse IgG was from Sigma (St. Louis, MO). The $4 \mathrm{~N} 1 \mathrm{~K}$ and RHD peptides were purchased from Bachem (Philadelphia, PA) and reconstituted in sterile distilled water. Fucoidan, pertussis toxin, and $N$-formyl-Met-Leu-Phe (fMLP) were purchased from Sigma and reconstituted in sterile distilled water. $\mathrm{A} \beta$ peptides corresponding to human $\mathrm{A} \beta$ amino acids $25-35$ and $1-42$ were purchased from American Peptide Co. (Sunnyvale, CA), and that corresponding to amino acids 1-40 was from California Peptide Research, Inc. (Napa, CA). The peptides were resuspended in sterile distilled water followed by incubation at $37^{\circ} \mathrm{C}$ for 1 week to allow fibrillarization. The method used to fibrillarize A $\beta 25-35,1-40$, and 1-42 has been well characterized (Burdick et al., 1992; Lorenzo and Yankner, 1994; Terzi et al., 1994); however, the composition of the fibrillar solutions was not tested and may have included $\mathrm{A} \beta$ oligomers as well as fibrils. Nonfibrillar A $\beta 1-40$ was prepared by resuspending the peptide in sterile distilled water and used immediately. Soluble RAGE (sRAGE) was a gift from Dr. Mark Kindy (University of Kentucky). The anti-phospho-Tyr antibody 4G10 was obtained from Upstate Biotechnology (Lake Placid, NY). Antiphospho-extracellular-regulated kinase (ERK) antibody was obtained from New England Biolabs (Beverly, MA). Anti-ERK2 antibody was from Santa Cruz Biotechnology (Santa Cruz, CA). Anti-IL-1 $\beta$ was obtained from the National Cancer Institute (Frederick, MD). Affinity-purified horseradish peroxidase-conjugated sheep anti-mouse and donkey anti-rabbit antibodies were from Amersham Biosciences (Piscataway, NJ).

Tissue culture. Human THP-1 monocytes (American Type Culture Collection, Manassas, VA) were grown in RPMI 1640 medium (Whittaker Bioproducts, Walkersville, MD) containing 10\% heat-inactivated fetal bovine serum (FBS), $5 \times 10^{-5} \mathrm{M} 2$-mercaptoethanol, $5 \mathrm{~mm}$ HEPES, and $15 \mu \mathrm{g} / \mathrm{ml}$ gentamycin in $5 \% \mathrm{CO}_{2}$. Microglia were derived from postnatal day 1-2 mouse brains (C57BL/6J) as described previously (McDonald et al., 1997).

Cell stimulation. THP-1 cells and microglia were collected and resuspended in $37^{\circ} \mathrm{C} \mathrm{HBSS}$ for $30 \mathrm{~min}$ at $37^{\circ} \mathrm{C}$ in the absence or presence of sRAGE, pertussis toxin, fucoidan, GST-CD36-(93-120), $4 \mathrm{~N} 1 \mathrm{~K}$, or the RHD peptide or at $4^{\circ} \mathrm{C}$ in the presence of anti- $\alpha_{1,2,4,5,6, v}$ or anti- $\beta_{1}$ antibody for intracellular signaling analysis. Cells were then stimulated by the addition of $60 \mu \mathrm{M} \mathrm{A} \beta$ peptides for $3 \mathrm{~min}$ at $37^{\circ} \mathrm{C}$, collected by centrifugation, and lysed at $4^{\circ} \mathrm{C}$ in Triton buffer (1\% Triton X-100, 20 mм Tris, pH 7.5, 100 mм NaCl, 40 mм NaF, 1 mм EDTA, 1 mм EGTA, and $1 \mathrm{~mm} \mathrm{Na} \mathrm{NO}_{4}$ ). All experiments were performed a minimum of three times.

IL-1 $\beta$ assay. THP- 1 cells were plated $48 \mathrm{hr}$ before stimulation in $2 \%$
FBS. The cells $\left(3 \times 10^{6}\right)$ were collected and resuspended in $37^{\circ} \mathrm{C} 0.5 \%$ FBS with $0.5 \mu \mathrm{g} / \mathrm{ml}$ lipopolysaccharide for $4 \mathrm{hr}$ in the presence of fucoidan, $4 \mathrm{~N} 1 \mathrm{~K}$, and RHD peptide and stimulated with $60 \mu \mathrm{M} \mathrm{A} \beta 25-35$. Cells were collected by centrifugation and lysed at $4^{\circ} \mathrm{C}$ in radioimmunoprecipitation assay (RIPA) buffer (1\% Triton X-100, 20 mm Tris, pH 7.5, $100 \mathrm{~mm} \mathrm{NaCl}, 40 \mathrm{~mm} \mathrm{NaF}, 0.2 \%$ SDS, $0.5 \%$ deoxycholate, 1 mм EDTA, 1 mM EGTA, and $1 \mathrm{~mm} \mathrm{Na}_{3} \mathrm{VO}_{4}$ ).

Immunoprecipitation and Western blotting. After cell lysis, insoluble material was removed by centrifugation at $10,000 \times g$ at $4^{\circ} \mathrm{C}$ for $10 \mathrm{~min}$. Protein concentrations were determined by the method of Bradford (1976) using bovine serum albumin as a standard. Lysates were added to $30 \mu \mathrm{l}$ of protein A-agarose with the primary antibody ( $2 \mu \mathrm{g}$ of primary antibody/mg of lysate) and incubated with rocking for $2 \mathrm{hr}$ at $4^{\circ} \mathrm{C}$. Immune complexes were washed three times in Triton X-100 buffer. Lysates and immune complexes were resolved by 7.5 or $12 \%$ SDS-PAGE and Western blotted with primary antibody (4G10, 1:1500), anti-phosphoERK (1:1000), anti-ERK2 (1:2000), anti-Fyn (1:1000), or anti-IL-1 $\beta$ (1: 1000 ) overnight at $4^{\circ} \mathrm{C}$. Antibody binding was detected by enhanced chemiluminescence (Pierce, Rockford, IL). IL-1 $\beta, 4 \mathrm{G} 10$, and phosphoERK blots were stripped by incubation in stripping buffer $(62.5 \mathrm{~mm}$ Tris, $\mathrm{pH} 6.8,100 \mathrm{~mm} \beta$-mercaptoethanol, and $2 \%$ SDS) for $30 \mathrm{~min}$ at $50^{\circ} \mathrm{C}$ and then reprobed with anti-Fyn or anti-ERK2 antibodies. Quantitation of the $\mathrm{A} \beta$-stimulated Tyr phosphorylation was obtained by imaging the ECL signal using a Bio-Rad (Hercules, CA) VersaDoc, and the integrated optical density of the individual lanes was obtained using Quantity One software.

Respiratory burst. Intracellular superoxide radical generation was assayed by measuring nitroblue tetrazolium (NBT) reduction (Pick, 1986; McDonald et al., 1997). THP- 1 cells $\left(2 \times 10^{6}\right)$ were resuspended at $37^{\circ} \mathrm{C}$ for $30 \mathrm{~min}$ in the presence or absence of fucoidan, anti-CD36 antibody, anti- $\beta_{1}$ antibody, or an isotype-specific mouse IgG and with $1 \mathrm{mg} / \mathrm{ml}$ NBT. Cells were collected by centrifugation and sonicated in $4^{\circ} \mathrm{C}$ RIPA buffer. NBT reduction was measured by the change in absorbance at 550 $\mathrm{nm}$. The assays were performed in triplicate.

Cell adhesion assay. THP-1 monocytes were preincubated with antibody or peptide antagonist for $30 \mathrm{~min}$ in $4^{\circ} \mathrm{C}$ serum-free RPMI 1640 medium. The fibrillar $\mathrm{A} \beta$ peptides $(2 \mu \mathrm{g})$ were applied directly to a glass slide and allowed to dry. The adherent $A \beta$ fibrils could be visualized by eye. Although the percentage of peptide that bound was not determined, it was constant between individual spots in each experiment. Approximately 50,000 cells were applied to either the glass slide or the $\mathrm{A} \beta$ fibrils and allowed to adhere for $5 \mathrm{~min}$. Cells were washed at $37^{\circ} \mathrm{C}$, and the number of adherent cells were counted microscopically. The data are reported as cell number bound per square millimeter. The assays were performed in triplicate.

Immunochemistry. Microglia were fixed in ice-cold acetone for $15 \mathrm{~min}$, washed, blocked with PBS containing 20\% goat serum, incubated with 20 $\mu \mathrm{g} / \mathrm{ml}$ mouse anti-murine CD36 IgA or control IgA for $60 \mathrm{~min}$, washed, incubated with $1 \mu \mathrm{g} / \mathrm{ml}$ biotinylated goat anti-mouse IgA for $30 \mathrm{~min}$ at room temperature, washed, and incubated with $2 \mathrm{mg} / \mathrm{ml}$ avidinconjugated Alexa 488 (Molecular Probes, Eugene, OR) in PBS at room temperature. All antibodies were diluted in PBS containing 3\% goat serum.

Statistical analysis. Experiments were done in triplicate. Mean values \pm SEM for each experiment were determined, and values statistically different from controls were calculated using one-way ANOVA. The Tukey-Kramer multiple-comparisons post test was used to determine $P$ values.

\section{Results}

\section{Stimulation of protein-Tyr phosphorylation in THP-1 monocytes by fibrillar $A \boldsymbol{\beta}$ peptides}

We have previously demonstrated that fibrillar $\mathrm{A} \beta$ peptides, $\mathrm{A} \beta 1-40, \mathrm{~A} \beta 1-42$, and $\mathrm{A} \beta 25-35$, stimulated protein-Tyr phosphorylation in THP-1 monocytes and microglia (McDonald et al., 1997, 1998; Combs et al., 1999). Quantitative analysis of the response revealed that the three peptides elicited similar increases in protein-Tyr phosphorylation in THP-1 cells, with the 


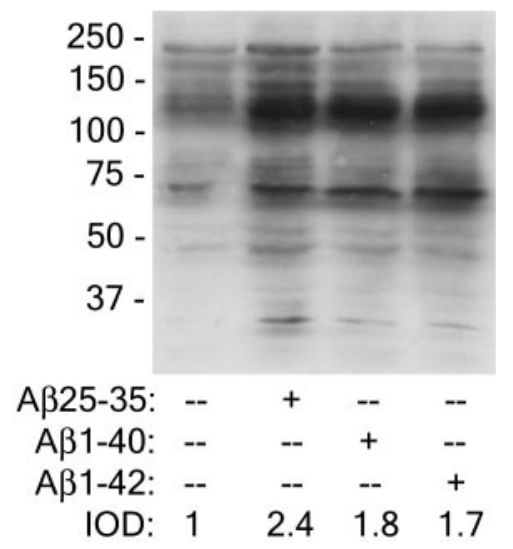

Figure 1. Fibrillar $A \beta 25-35,1-40$, and $1-42$ peptides stimulate comparable increases in protein-Tyr phosphorylation in THP-1 monocytes. THP-1 monocytes were stimulated with fibrillar $A \beta 25-35,1-40$, and $1-42$ peptides for 3 min. Cell lysates were analyzed by Western blot analysis using the anti-phospho-Tyr antibody 4G10. The integrated optical density (IOD) ratio of the protein-Tyr phosphorylation signal stimulated by the different $A \beta$ ligands was quantitated.

A $\beta 25-35$ peptide exhibiting a modestly greater response than the longer peptides (Fig. 1). These data indicate that fibrillar $\mathrm{A} \beta$ peptides containing the terminal 10 amino acids that form a $\beta$-pleated sheet are sufficient to stimulate intracellular signaling cascades (Terzi et al., 1994). The response to the various fibrillar $\mathrm{A} \beta$ peptides was qualitatively similar, indicating that they act through common mechanisms to initiate intracellular signaling events.

\section{Scavenger receptors mediate interactions of $A \beta$ fibrils with THP-1 monocytes and microglia}

Senile plaque-associated microglia are activated after the interaction of $\mathrm{A} \beta$ fibrils with microglia (Akiyama et al., 2000). Previous reports have provided evidence for a role for both SR-A and SR-B1 in the binding of fibrillar $A \beta$ peptides to neonatal microglia, resulting in the subsequent generation of ROS (El Khoury et al., 1996; Paresce et al., 1996; Husemann et al., 2001). Scavenger receptors constitute a structurally diverse family of cell surface receptors that exhibit broad substrate specificity and participate in both cellular adhesion and uptake of ligands (Krieger and Herz, 1994). Sulfated polysaccharides such as fucoidan act to inhibit SR-ligand interactions in an SR class-independent manner. We have verified that incubation of THP-1 monocytes with fucoidan inhibited the ability of these cells to bind to surfaces coated with fibrillar $\mathrm{A} \beta$ peptides (Fig. 2A). Because THP-1 monocytes do not normally express high levels of SR-A or SR-B1 unless differentiated into macrophages (Hsu et al., 1996), fucoidan-mediated inhibition of cell binding to $A \beta$ fibrils provoked us to examine the involvement of additional SR class members.

We examined whether the B class scavenger receptor CD36 participated in monocyte adhesion to fibrillar $A \beta$ and found that the binding of THP- 1 monocytes to $A \beta 25-35$ and $A \beta 1-40$ fibrils was inhibited by a peptide derived from the extracellular domain of CD36 (residues 93-120 fused to GST; Fig. 2B) with a $K_{\mathrm{i}}$ of $\sim 50 \mathrm{~nm}$ (Fig. $2 C$ ). The inhibition of cell adhesion was specific to GST-CD36-(93-120) fusion peptide, because GST alone did not have any effect on cell binding to $\mathrm{A} \beta$ fibrils (Fig. $2 D$ ). Amino acids 93-120 of CD36 represent the minimal region of the CD36 receptor required for the binding of the fibrillar angiogenesis peptide thrombospondin-1 (TSP-1; Pearce et al., 1995). Anti-
A.

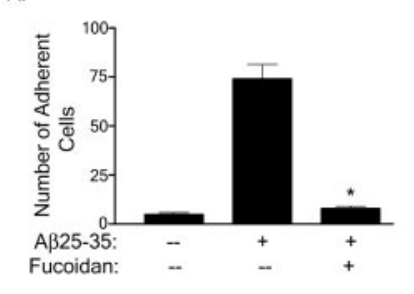

C.
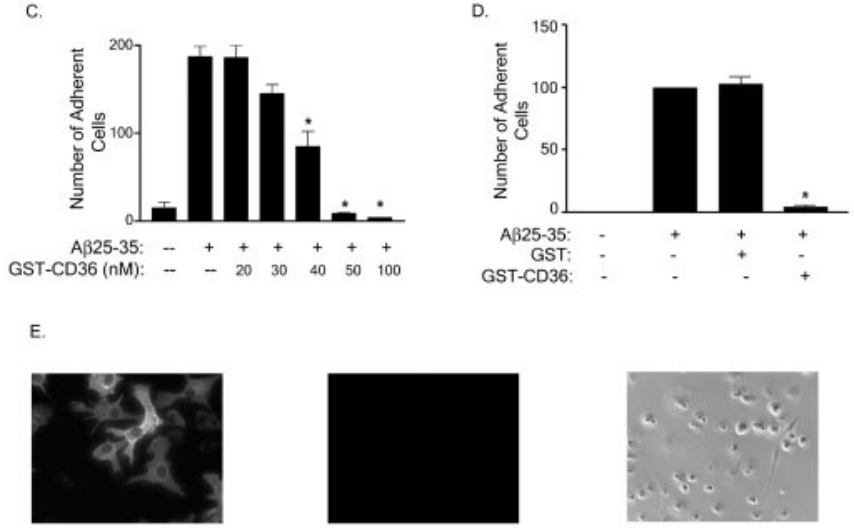

Figure 2. Scavenger receptors are expressed on microglia and are involved in cellular adhesion to fibrillar $A \beta$. THP-1 monocytes were preincubated in serum-free RPMI 1640 medium with $300 \mu \mathrm{g} / \mathrm{ml}$ fucoidan ( $A$ ) or $100 \mathrm{~nm} \mathrm{GST-CD36-(93-120)} \mathrm{(B),} \mathrm{and} \mathrm{the} \mathrm{cell} \mathrm{suspension} \mathrm{was}$ applied to the fibrillar $A \beta(2 \mu \mathrm{g})$ bound to a glass slide. Dose-dependent inhibition of adhesion of THP-1 monocytes to A $\beta 25-35$ fibrils in the presence of 20-100 nm GST-CD36-(93-120) (C) and $50 \mathrm{~nm}$ GST or GST-CD36 (D) was evaluated. Cells were treated as described in $(A, B)$. The number of adherent cells per square millimeter was recorded. The data shown represent the mean \pm SEM of triplicate determinations. $\left({ }^{*} p<0.001\right) E$, Primary murine microglia were stained with an anti-CD36 antibody (left panel) or control lg (middle panel) as described in Materials and Methods or visualized by phase microscopy (right panel).

CD36 antibodies directed to other epitopes on CD36 did not inhibit cell adhesion (data not shown; Coraci et al., 2002), indicating that the interaction of $A \beta$ fibrils was restricted to the same domain as that required for TSP-1 binding. We wished to verify that CD36 was expressed on microglia. We demonstrated the expression of CD36 on neonatal murine microglia by fluorescent immunohistochemistry (Fig. 2E). Microglia stained with control Ig showed no staining (Fig. $2 E$ ).

A primary goal of these studies was to establish the identity of cell surface receptors linked to activation of intracellular signaling pathways. CD36 is physically associated with members of the Src family of Tyr kinases (Huang et al., 1991; Bull et al., 1994), which transduce signals from this receptor (Jimenez et al., 2000). We have previously demonstrated that exposure of murine microglia and THP-1 monocytes to A $\beta 25-35, \mathrm{~A} \beta 1-40$, or $\mathrm{A} \beta 1-42$ fibrils resulted in the activation of Tyr kinase-based signaling pathways, including activation of the Src family kinase Lyn and Syk, leading to the activation of the ERK and p38 MAP kinase cascades (McDonald et al., 1997, 1998; Combs et al., 1999). We found that exposure of cells to CD36 antagonists, either fucoidan or the GST-CD36-(93-120) peptide, inhibited the A $\beta$-stimulated activation of intracellular protein-Tyr phosphorylation and subsequent ERK phosphorylation in THP-1 monocytes (Fig. 3A, B) and microglia (Fig. 3C). A control GST peptide did not have any effect on $\mathrm{A} \beta$-stimulated intracellular signaling (data not shown). We were unable to demonstrate ligand-dependent changes in the association of Src family kinases with CD36 (data not shown). 
A.

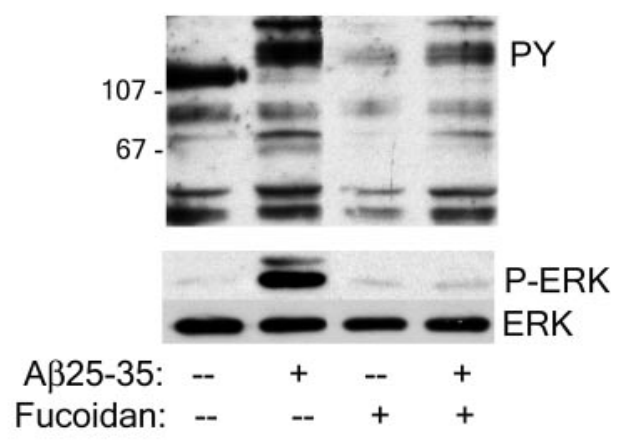

B.

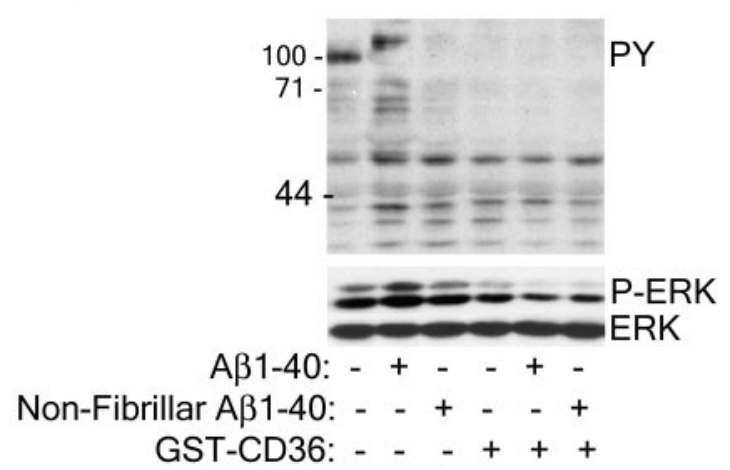

C.

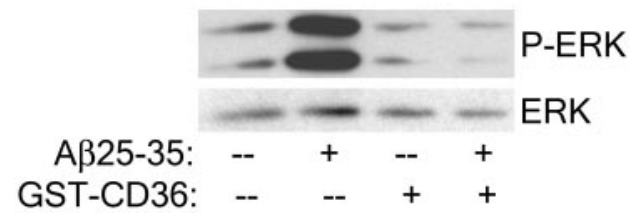

Figure 3. Scavenger receptors mediate $A \beta$ stimulation of intracellular Tyr signaling cascades in THP-1 monocytes and microglia. THP-1 monocytes were preincubated with $300 \mu \mathrm{g} / \mathrm{ml}$ fucoidan (A) or $100 \mathrm{~nm}$ GST-CD36-(93-120) (B) for 30 min before stimulation with fibrillar or nonfibrillar A $\beta$. C, Primary murine microglia were treated with $100 \mathrm{~nm}$ GST-CD36-(93-120) before $A \beta$ stimulation. (ell lysates were analyzed by Western blot using the anti-phospho-Tyr antibody $4 \mathrm{G} 10$ (PY) or an anti-phospho-ERK antibody (P-ERK). P-ERK blots were stripped and reprobed with an anti-ERK antibody (ERK) as a protein-loading control.

The $\boldsymbol{\alpha}_{6} \boldsymbol{\beta}_{1}$-integrin and the integrin-associated protein CD47 mediate $\mathbf{A} \boldsymbol{\beta}$-stimulated phospho-Tyr signaling and adhesion in THP-1 monocytes and microglia

The integrins represent a family of molecules that activate intracellular signaling cascades and promote adhesion to other cells as well as matrix proteins. The identification of the signaling molecules transducing $\mathrm{A} \beta$-stimulated responses suggested the participation of this superfamily of receptors in the binding of other fibrillar proteins (McDonald et al., 1997, 1998). Evidence for the involvement of the $\beta_{1}$-integrin as an element of the $\mathrm{A} \beta$ receptor complex was obtained using a peptide containing the consensus
A.

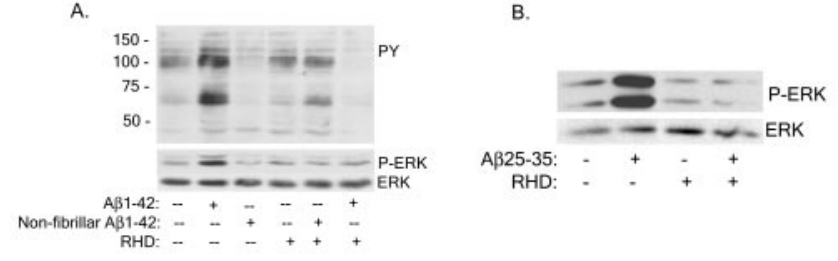

C.

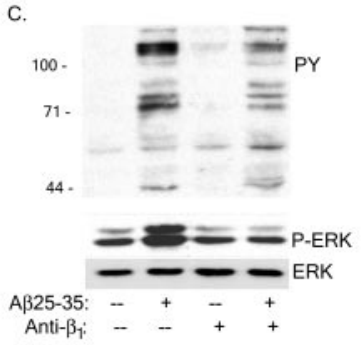

D.

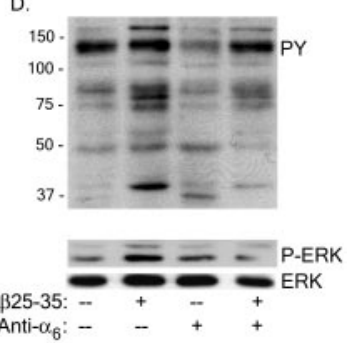

E.

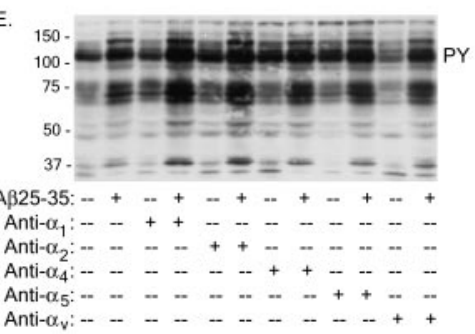

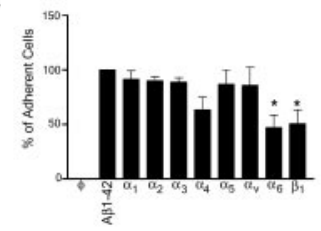

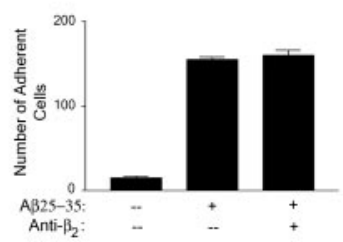

Figure 4. The $\alpha_{6} \beta_{1}$-integrin is required for $A \beta$ binding and stimulation of THP- 1 monocytes. A, THP- 1 monocytes were preincubated with $100 \mu \mathrm{g} / \mathrm{ml} \mathrm{RHD} \mathrm{peptide} \mathrm{for} 30$ min before fibrillar or nonfibrillar $A \beta 1-40$ stimulation. Cell lysates were analyzed by Western blot using the anti-phospho-Tyr antibody 4G10 (PY) or an anti-phospho-ERK antibody (P-ERK). B, Primary murine microglia were pretreated with RHD peptide as described in $A$ but stimulated with fibrillar A $\beta 25-35$ and analyzed by P-ERK Western blot analysis of cell lysates. Blots were stripped and reprobed with anti-ERK antibody (ERK) as a protein-loading control. C $-E$, THP-1 monocytes were preincubated with antibodies ( $40 \mu \mathrm{g} / \mathrm{ml})$ to the $\beta_{1}(C), \alpha_{6}(D)$, and $\alpha_{1,2,4,5, \mathrm{v}}$ $(E)$ integrins as described in $A$ and stimulated with fibrillar $A \beta 25-35$. Cell lysates were evaluated by Western blot analysis, using the 4G10, P-ERK, and ERK antibodies. F, G, Adhesion of THP-1 cells to fibrillar $A \beta$ evaluated by preincubation in serum-free RPMI 1640 medium with antibodies to the $\alpha_{1-6,{ }}{ }$ and $\beta_{1}$-integrin subunits $(40 \mu \mathrm{g} / \mathrm{ml} ; F)$ or anti- $\beta_{2}$-integrin subunit $(40 \mu \mathrm{g} / \mathrm{ml} ; G)$ and added to $2 \mu \mathrm{g}$ of fibrillar $\mathrm{A} \beta$ bound to a glass slide. The number of adherent cells per square millimeter was recorded. The data shown represent the mean \pm SEM of triplicate determinations $\left({ }^{*} p<0.05 ; F\right)$.

$\beta_{1}$-integrin-binding epitope RHD. This peptide comprises residues $1-11$ of $\mathrm{A} \beta$ (DAEFRHDSGYE) and contains a sequence closely related to the canonical integrin recognition site peptide RGD. However, although RGD binds to most integrins, heterodimers containing the $\beta_{1}$ subunit display an RHD binding preference (Ghiso et al., 1992). The RHD-containing peptide inhibited $\mathrm{A} \beta$-mediated intracellular Tyr and ERK phosphorylation in THP-1 monocytes (Fig. 4A) and microglia (Fig. 4B). It is evident that the epitope present in the fibrillar $A \beta$ species that interacts with the $\beta_{1}$-integrin is distinct from the RHD sequence, because fibrils derived from $A \beta 25-35$ are also antagonized by the anti- $\beta_{1}$ antibody. To confirm that the $\beta_{1}$-integrin subunit was 
specifically involved in mediating $\mathrm{A} \beta$ stimulation of protein-Tyr phosphorylation, THP-1 monocytes were incubated with an anti- $\beta_{1}$ antibody. Western blot analysis confirmed inhibition of $\mathrm{A} \beta$-mediated intracellular phospho-Tyr signaling by the $\beta_{1}$ antibody (Fig. 4C). To identify the corresponding $\alpha$-integrin subunit, we used a panel of antibodies and found that an antibody to $\alpha_{6}$ (Fig. $4 D$ ), but not other $\alpha$-integrin subunits (Fig. $4 E ; \alpha_{3}$-integrin data not shown), inhibited both intracellular phospho-Tyr signaling and ERK phosphorylation.

One of the primary functions of integrins is to mediate cellular adhesion, and we next evaluated which integrins were responsible for cellular binding to $\mathrm{A} \beta$ fibrils using a panel of antibodies to $\beta_{1}$-integrin partners. We found that antibodies to the $\alpha_{6}$ - and $\beta_{1}$-integrin subunits decreased cell adhesion of THP-1 monocytes to A $\beta 1-42$ fibrils. We were unable to implicate other $\alpha$ subunits $\left(\alpha_{1-5}\right.$ and $\alpha_{\mathrm{v}}$; Fig. $\left.4 F\right)$ or the $\beta_{2}$ (Fig. $4 G$ ) and $\beta_{3}$ (data not shown) integrin subunits in cellular adhesion. These data demonstrate that the $\alpha_{6} \beta_{1}$-integrin is the principal integrin species responsible for the interaction of $A \beta$ fibrils with the cells.

The integrin-associated protein CD47 is a transmembrane receptor expressed on many cell types and acts primarily to modulate integrin-dependent signaling through its physical and functional association with integrins (Porter and Hogg, 1998) as well as intracellular signaling molecules, including the Tyr kinases Lyn and Syk (Chung et al., 1997). We tested whether CD47 was involved in $\mathrm{A} \beta$-stimulated intracellular signaling cascades and adhesion events. A peptide antagonist of CD47, $4 \mathrm{~N} 1 \mathrm{~K}$, is derived from the cell-binding domain of TSP-1 and specifically blocks the interaction of CD47 with TSP-1 (Chung et al., 1997). Incubation of THP-1 monocytes with $4 \mathrm{~N} 1 \mathrm{~K}$ inhibited the ability of THP-1 monocytes to adhere to $\mathrm{A} \beta 1-42$ fibrils (Fig. $5 A$ ). In addition, blocking the association of CD47 with $\mathrm{A} \beta$ fibrils inhibited $\mathrm{A} \beta$ fibril stimulation of intracellular protein-Tyr and ERK phosphorylation in THP-1 monocytes (Fig. 5B).

\section{$\mathrm{A} \boldsymbol{\beta}$-stimulated signaling requires elements of the $\mathrm{A} \boldsymbol{\beta}$-binding receptor complex}

It has been well documented that exposure of microglia and monocytes to fibrillar forms of $\mathrm{A} \beta$ stimulates NADPH oxidase activation and a respiratory burst, resulting in the generation and secretion of ROS (Meda et al., 1995; El Khoury et al., 1996; McDonald et al., 1997; Bianca et al., 1999; Van Muiswinkel et al., 1999). Preincubation of THP-1 monocytes with fucoidan, an anti-CD36 antibody, and an anti- $\beta_{1}$-integrin subunit antibody inhibited the $\mathrm{A} \beta$-stimulated respiratory burst (Fig. $6 A-C$ ). Thus, these data support an essential role for scavenger receptors, specifically CD36, as well as the $\beta_{1}$-integrin in mediating the $\mathrm{A} \beta$ stimulated respiratory burst in microglia cells and monocytes.

The proinflammatory cytokine IL- $1 \beta$ is elevated in $\mathrm{AD}$ and augments the inflammatory response of the disease through its autocrine and paracrine actions (Akiyama et al., 2000). It has previously been demonstrated that microglia secrete IL- $1 \beta$ as well as other cytokines on exposure to fibrillar $\mathrm{A} \beta$ and other immune stimuli (Araujo and Cotman, 1992; Meda et al., 1995, 1996, 1999; Lorton et al., 1996; Fiala et al., 1998; Murphy et al., 1998; Combs et al., 2000, 2001). We therefore assessed the role of the putative $A \beta$ receptors in $A \beta$-stimulated IL- $1 \beta$ production. The $4 \mathrm{hr}$ time course required to measure IL-1 $\beta$ levels in response to extracellular stimuli technically excluded our ability to assess the effects of the occupancy of the individual receptors on this response. However, blocking the association of $A \beta$ fibrils with the $\mathrm{A} \beta$ receptor complex using antagonists of CD 47 , the $\beta_{1}$-integrin, and scavenger receptors inhibited $\mathrm{A} \beta$-mediated stimulation of
A.

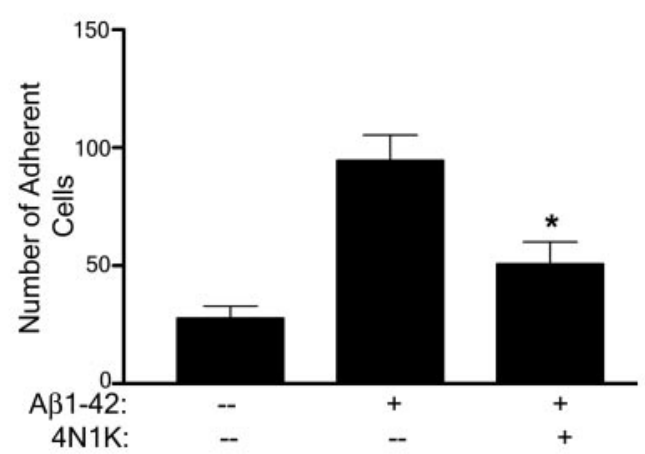

B.

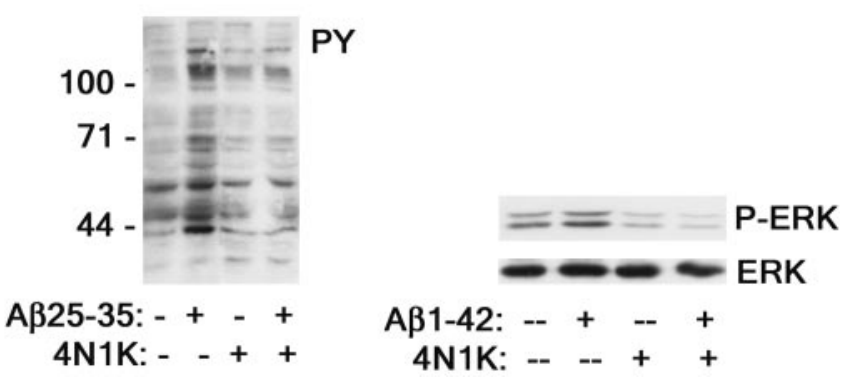

Figure 5. Inhibition of CD47 interactions with $A \beta$ fibrils blocks $A \beta$-mediated THP-1 monocyte activation. $A$, THP-1 monocytes were preincubated in serum-free RPMI 1640 medium with $100 \mu \mathrm{M}$ CD47 antagonist peptide 4N1K and added to $2 \mu \mathrm{g}$ of fibrillar A $\beta$ bound to a glass slide. The number of adherent cells per square millimeter was recorded. The data shown represent the mean \pm SEM of triplicate determinations $\left({ }^{*} p<0.01\right)$. $B$, THP-1 monocytes were preincubated with $100 \mu \mathrm{m} 4 \mathrm{~N} 1 \mathrm{~K}$ for 30 min before fibrillar $A \beta 25-35$ or $A \beta 1-42$ stimulation. Cell lysates were analyzed by Western blot using the anti-phospho-Tyr antibody $4 \mathrm{G} 10(P Y)$ or an antiphospho-ERK antibody (P-ERK). The P-ERK blot was stripped and reprobed with an anti-ERK antibody (ERK) as a protein-loading control.

IL- $1 \beta$ production (Fig. $6 D$ ). Therefore, the engagement of the $\mathrm{A} \beta$-binding receptor complex is required for the ability of $\mathrm{A} \beta$ fibrils to mediate intracellular changes and subsequent production of neurotoxic and proinflammatory factors.

To formally test whether the concerted actions of the receptor elements were required for the activation of intracellular signaling cascades, we evaluated the effects of antagonists of the individual receptor elements on the activation of Src kinases. We report that Fyn, like its family member Lyn, is activated in response to $\mathrm{A} \beta$ stimulation. Importantly, Fyn phosphorylation is dependent on the interaction of each receptor with fibrillar $\mathrm{A} \beta$ (Fig. 7). The activation of Fyn and its association with downstream signaling elements are inhibited after blockade of scavenger receptors, specifically CD36, CD47, and the $\beta_{1}$-integrin (Fig. 7).

\section{$A G_{i}$-linked receptor is not involved in $A \beta$ stimulation of Tyr} kinase-based signaling pathways in THP-1 monocytes

The heterotrimeric small G-protein $G_{i}$ is an effector of some CD47-linked receptors and the chemotactic FPR (Gao et al., 1996; Chung et al., 1997; Lorton, 1997; Frazier et al., 1999; Wang et al., 1999; Le et al., 2001). We tested the involvement of $\mathrm{G}_{\mathrm{i}^{-}}$ proteins in $A \beta$-mediated stimulation of intracellular signaling cascades. Inhibition of $\mathrm{G}_{\mathrm{i}}$ action by pertussis toxin treatment of THP-1 monocytes did not affect $\mathrm{A} \beta$ stimulation of protein-Tyr phosphorylation or ERK phosphorylation (Fig. 8). The specificity of pertussis toxin activity was monitored using the chemotactic peptide fMLP, which stimulates ERK phosphorylation after 
A.

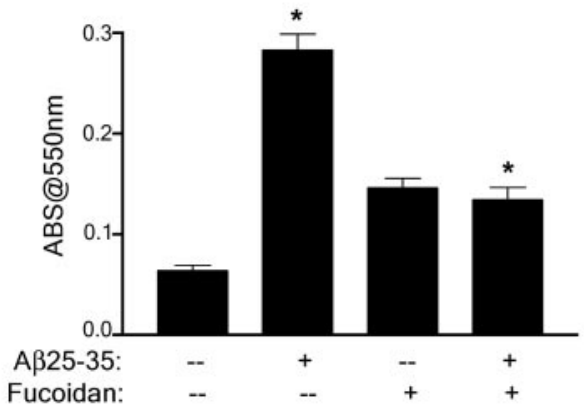

B.

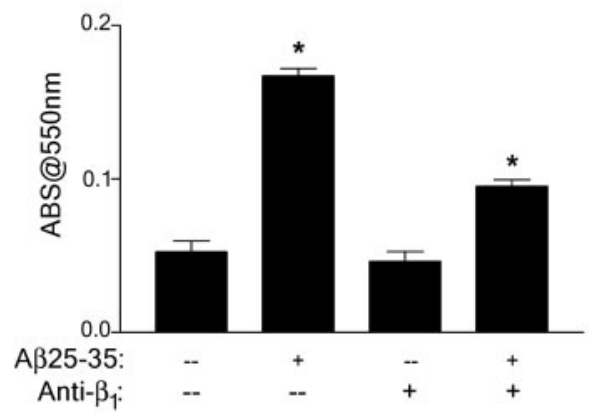

C.

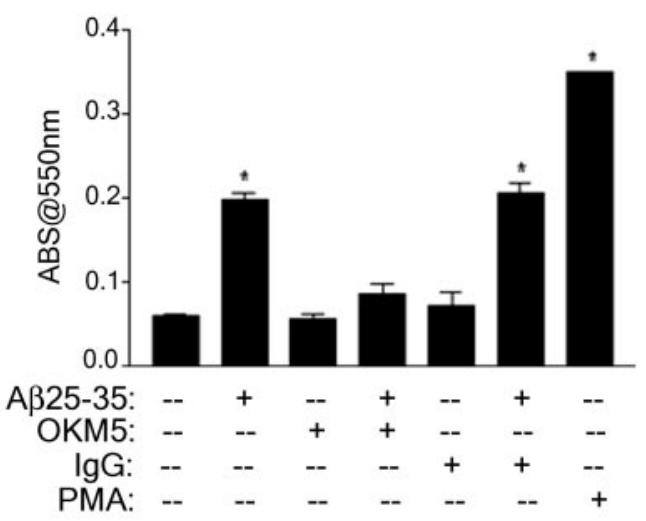

D.

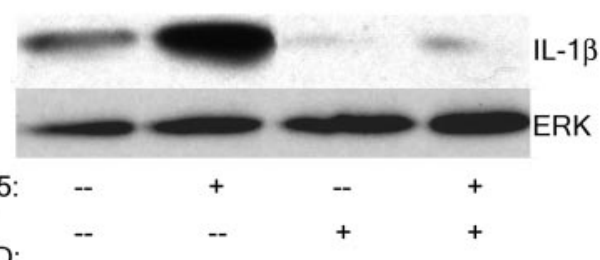

Figure 6. The $A \beta$ receptor complex mediates the stimulation of ROS and IL-1 $\beta$ production. $A-C$, THP-1 monocytes were incubated with fucoidan ( $300 \mu \mathrm{g} / \mathrm{ml} ; A)$, anti- $\beta_{1}(40 \mu \mathrm{g} / \mathrm{ml} ; B)$, isotypespecific lgG (C) phorbol 12-myristate 13-acetate (PMA, C) or anti-CD36 (OKM5, $40 \mu \mathrm{g} / \mathrm{ml} ; C)$ in serum-free RPMI containing NBT and stimulated with fibrillar $A \beta 25-35$ for 25 min at $37^{\circ}$. Superoxide anion generation was measured by the change in absorbance at $550 \mathrm{~nm}$. The data shown represent the mean \pm SEM of triplicate determinations $\left({ }^{*} p<0.001 ; A-C\right)$. D, Mature IL- $1 \beta$ production in A $\beta$-stimulated THP- 1 monocytes was evaluated in the presence of $300 \mu \mathrm{g} / \mathrm{ml}$ fucoidan, 100 $\mu \mathrm{M} 4 \mathrm{~N} 1 \mathrm{~K}$, and $100 \mu \mathrm{g} / \mathrm{ml} \mathrm{RHD}$ peptide. Cell lysates were resolved by $12 \%$ SDS-PAGE, transferred to polyvinylidene difluoride, and probed with the anti-IL-1 $\beta$ antibody. The blot was stripped and reprobed with an anti-ERK antibody (ERK) as a protein-loading control.
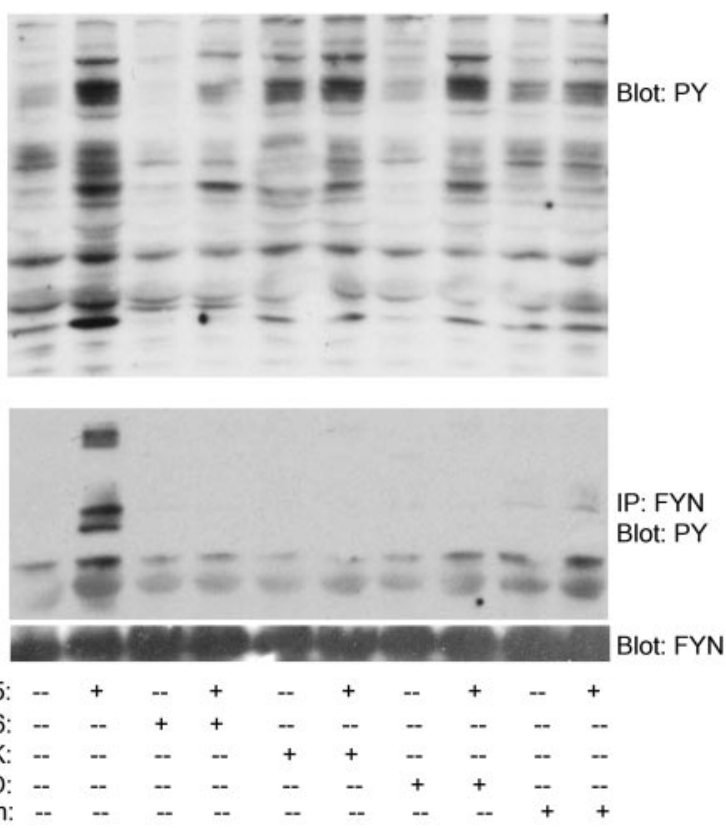

Figure 7. Members of the $A \beta$ receptor complex are required for $A \beta$ stimulation of Fyn phosphorylation. THP-1 monocytes were preincubated in serum free RPMI 1640 medium with $300 \mu \mathrm{g} / \mathrm{ml}$ fucoidan, $100 \mathrm{~nm}$ GST-CD36-(93-120), $100 \mu \mathrm{m}$ 4N1K, or $100 \mu \mathrm{g} / \mathrm{ml}$ RHD for $30 \mathrm{~min}$ before stimulation with fibrillar $A \beta$. Cell lysates were immunoprecipitated with the anti-Fyn JD3 antibody. Cell lysates and immunoprecipitates were resolved by 7.5\% SDS-PAGE and analyzed by Western blot using the anti-phospho-Tyr antibody 4G10 (PY). Blots were stripped and reprobed with an anti-Fyn JD3 antibody (FYN) as a protein-loading control.

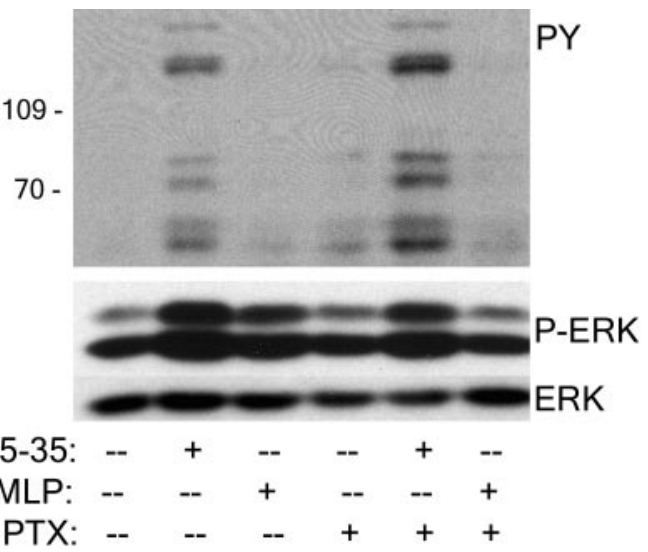

Figure 8. $\quad A G_{i}$-linked receptor is not involved in $A \beta$-stimulated intracellular signaling. THP-1 monocytes were preincubated with $200 \mathrm{ng} / \mathrm{ml}$ pertussis toxin (PTX) for $30 \mathrm{~min}$ at $37^{\circ} \mathrm{C}$ and stimulated with $A \beta 25-35$ or $1 \mu \mathrm{m}$ fMLP for 3 min. Western blots of cellular lysates were probed with the anti-phospho-Tyr antibody 4 G10 (PY) or with the anti-phospho-ERK antibody $(P$-ERK). Blots were stripped and reprobed with the anti-ERK antibody (ERK).

binding of FPR receptors in a pertussis toxin-sensitive manner. We conclude that a $\mathrm{G}_{\mathrm{i}}$-linked receptor is not involved in $\mathrm{A} \beta$ stimulation of intracellular signaling in THP-1 monocytes, and the participation of CD47 in this event is independent of its ability to functionally associate with $\mathrm{G}_{\mathrm{i}}$-proteins.

\section{RAGE does not mediate A $\beta$ stimulation of Tyr kinase-based} signaling pathways in THP-1 monocytes

RAGE was previously reported to be an $\mathrm{A} \beta$-binding protein, capable of interacting with both fibrillar and nonfibrillar forms of $\mathrm{A} \beta$ and provoking microglia activation (Yan et al., 1996; Lue et al., 2001). However, it is unclear whether there is a preference of 


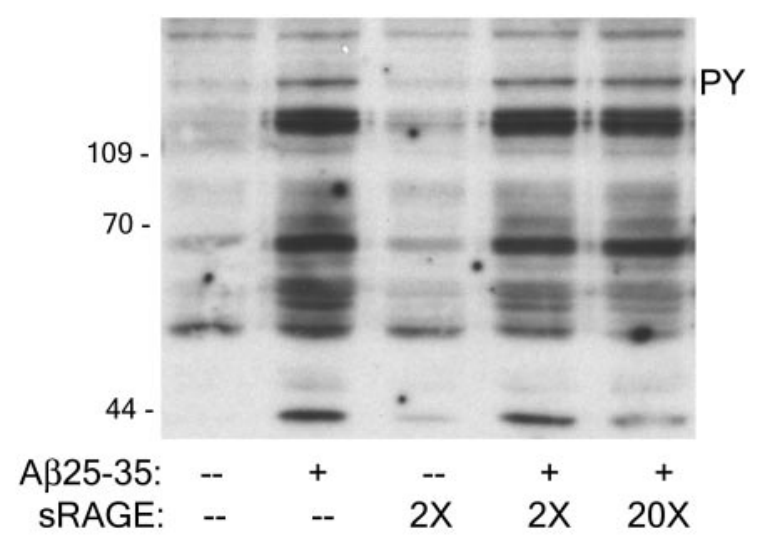

Figure 9. RAGE is not involved in A $\beta$-mediated intracellular signaling. THP-1 monocytes were incubated for 30 min at $37^{\circ} \mathrm{C}$ and stimulated with $A \beta 25-35,2$ or $20 \times$ sRAGE, or both for 3 min. Western blots of cellular lysates were probed with the anti-phospho-Tyr antibody $4 \mathrm{G} 10(P Y)$.

RAGE for aggregated forms of A $\beta$ (Yan et al., 1996). We (McDonald et al., 1997, 1998; Combs et al., 1999) and others (Bianca et al., 1999) have failed to demonstrate that engagement of RAGE on microglia or THP-1 monocytes stimulates cellular effects similar to those induced by fibrillar $\mathrm{A} \beta$. In the present study, we extended our analysis of RAGE as a candidate $\mathrm{A} \beta$-binding receptor mediating stimulation of intracellular signaling. The addition of sRAGE at $2 \times(120 \mu \mathrm{M})$ or $20 \times(1.2 \mathrm{~mm})$ the concentration of fibrillar $A \beta$ did not alter $A \beta$-mediated stimulation of protein-Tyr phosphorylation, as demonstrated by Western blot analysis (Fig. 9). We verified that sRAGE alone did not affect the ability of $A \beta$ fibrils to stimulate intracellular signaling, nor did sRAGE alone stimulate any changes in intracellular Tyr phosphorylation. Although we cannot rule out that RAGE may participate in the adhesion of cells to $A \beta$ and act in common with other cell surface proteins such as SR-A, we do not find evidence for the involvement of RAGE in $\mathrm{A} \beta$-mediated stimulation of intracellular signaling cascades.

\section{Discussion}

There has been substantial interest in the identity of cell surface molecules that bind $\mathrm{A} \beta$, because this represents the first potential point of intervention in the events leading to the pathophysiology of $\mathrm{AD}$. Our approach to the identification of microglial A $\beta$ receptors derived from consideration of the mechanisms through which macrophages interact with foreign elements, including protein fibrils. These cells use ensembles of receptors whose individual receptor elements exhibit relatively broad substrate specificity. The resulting receptor complex can mediate adhesion, migration, a respiratory burst, or proinflammatory responses. For example, the fibrillar proteins Bordetella pertussis filamentous hemagglutinin (FHA) and TSP-1 provoke cellular activation, a response similar to that observed in $\mathrm{A} \beta$-stimulated microglia. TSP- 1 interacts with CD36, CD47, and $\beta_{1}$ - and $\beta_{3}$-integrins and several other cell surface proteins (Bornstein, 1995), whereas FHA binds to monocytes via CD87 (urokinase receptor), $\alpha_{\mathrm{m}} \beta_{2^{-}}$ and $\alpha_{\mathrm{v}} \beta_{3}$-integrins, and CD47 (Ishibashi et al., 1994; Wong et al., 1996). Thus, we reasoned that $A \beta$ fibrils, which consist of repetitive units linked through C-terminal $\beta$-pleated sheet domains, may use some of the same receptors to interact with microglia and monocytes. Importantly, we evaluated the participation of candidate receptor elements by monitoring the ability of these molecules to stimulate $\mathrm{A} \beta$-activated intracellular signaling path-

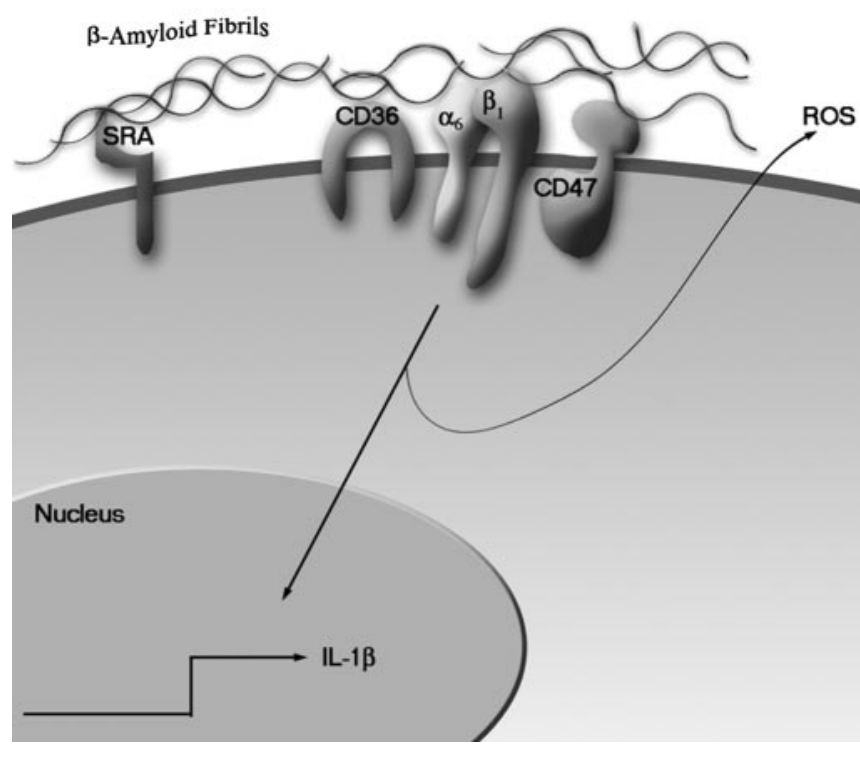

Figure 10. Model of $A \beta$ fibril interaction with a microglial cell surface receptor complex resulting in activation of intracellular signal transduction cascades.

ways whose activation is functionally linked to the production and secretion of proinflammatory and neurotoxic factors (McDonald et al., 1997; Bianca et al., 1999; Combs et al., 1999; Meda et al., 1999).

We report the identification of a multicomponent $\mathrm{A} \beta$ receptor complex consisting of CD36, $\alpha_{6} \beta_{1}$-integrin, and CD 47 . This complex mediates the adhesion of $\mathrm{A} \beta$ fibrils to microglia and subsequent activation of intracellular Tyr kinase-based signal transduction cascades, leading to the stimulation of a respiratory burst and IL-1 $\beta$ cytokine production (Fig. 10). It is significant that this receptor does not interact with nonfibrillar forms of $\mathrm{A} \beta$, whereas association with all fibrillar forms of $\mathrm{A} \beta$ was shown to elicit cellular responses (Pike et al., 1993; Lorton et al., 1996; McDonald et al., 1997, 1998; Combs et al., 1999).

Scavenger receptors are expressed on cells of monocytic lineage and interact with a structurally diverse range of ligands. The A class of SRs has been shown to participate in binding of $A \beta$ by microglia and has been implicated in chemotaxis, ROS generation, and $\mathrm{A} \beta$ peptide uptake (Hartung et al., 1986; Klegeris et al., 1994; Meda et al., 1995; El Khoury et al., 1996; Paresce et al., 1996). An exclusive role for SR-A in these events appears unlikely in view of recent reports that microglia from SR-A null animals are only modestly impaired in their ability to bind $\mathrm{A} \beta$ peptides (Husemann et al., 2001). Moreover, transgenic animals overexpressing the amyloid precursor protein but lacking SR-A expression exhibited levels of amyloid deposition similar to those of SR-A-expressing control animals (Huang et al., 1999). The compensatory action of B-class SRs may explain these findings.

We have provided evidence that the B-class SR CD36 plays an essential role in both the binding of $\mathrm{A} \beta$ fibrils to the cells and the initiation of intracellular signaling events. This view is supported by the report that macrophage binding to oxidized low-density lipoprotein is mediated by SR-A, whereas subsequent intracellular production of $\mathrm{H}_{2} \mathrm{O}_{2}$ is dependent on CD36 (Maxeiner et al., 1998). Moreover, despite considerable work, it has not been possible to conclusively show that SR-A acts independently to elicit activation of intracellular signaling cascades. CD36 is physically associated with Src family protein kinases, and it has recently been demonstrated that TSP-1 binding results in the activation of 
these Tyr kinases (Jimenez et al., 2000). Importantly, TSP-1 and $\mathrm{A} \beta$ peptides interact with a common domain on CD36, and we have demonstrated that binding of $\mathrm{A} \beta$ fibrils to microglia and monocytes elicits the activation of the Src family kinases Lyn and Fyn (McDonald et al., 1997; Combs et al., 1999). These data support our hypothesis that CD36 (and possibly SR-BI) is a critical component of the $\mathrm{A} \beta$ receptor complex linking fibril binding to stimulation of signal transduction pathways and that SR-A acts primarily to tether $\mathrm{A} \beta$ fibrils to the cell surface of microglia and is not critical for $A \beta$ stimulation of intracellular signaling events (Maxeiner et al., 1998; McDonald et al., 1998; Husemann et al., 2001).

While this manuscript was under review, Coraci et al. (2002) and Moore et al. (2002) published compelling evidence that $\mathrm{CD} 36$ acts as a receptor for $\mathrm{A} \beta$ fibrils and participates in both cellular adhesion and initiation of intracellular signaling events. Their observations are consistent with those reported here and provide further support for critical involvement of this scavenger receptor in $\mathrm{A} \beta$-stimulated activation of microglia.

Integrins are likely candidate receptors for $A \beta$ on microglia cells, because they promote adhesion to other cells and matrix proteins. We have shown that the $\alpha_{6} \beta_{1}$-integrin is a central element of the receptor complex and is essential for eliciting a cellular response to $A \beta$ and adhesion of $A \beta$ fibrils. Ligation of the $\beta_{1}$-integrin subunit has been shown to increase the protein-Tyr phosphorylation of paxillin, focal adhesion kinase, Syk, and Fyn, leading to the production of proinflammatory cytokines such as IL-1 $\beta$ (Lin et al., 1995; Chen et al., 2000). Many of the Tyr kinases that are stimulated by $\mathrm{A} \beta$ interaction with microglia and monocytic lineage cells are also components of integrin signaling pathways, including those linked to ERK phosphorylation (McDonald et al., 1997, 1998; Combs et al., 1999). It was previously reported that the $\alpha_{5} \beta_{1}$-integrin recognizes nonfibrillar $\mathrm{A} \beta$ (Matter et al., 1998). However, we did not detect any effect of a blocking antibody directed against $\alpha_{5}$. Thus, $\alpha_{5} \beta_{1}$ is unlikely to be involved in microglial activation by fibrillar $\mathrm{A} \beta$ in $\mathrm{AD}$.

We have also implicated CD47 in mediating $\mathrm{A} \beta$ stimulation of THP-1 monocytes and microglia. CD47 is an integral membrane protein that functionally interacts with both $\beta_{1^{-}}$and $\beta_{3^{-}}$ integrins, where it serves to modulate integrin signaling functions and cellular adhesion. Importantly, CD47 physically interacts with both integrins and intracellular signaling elements and may act to assemble signaling complexes and functionally integrate signals generated through ligand binding at the cell surface (Porter and Hogg, 1998). In addition, CD47 can act independently to promote cell-cell adhesion through its interactions with fibrillar proteins such as TSP-1 and cell surface proteins on adjacent cells (Jiang et al., 1999; Babic et al., 2000) and has been demonstrated to have a role in integrin-independent signaling events (Brown and Frazier, 2001). We have demonstrated a critical requirement for CD47 in cellular binding of fibrillar $\mathrm{A} \beta$ and the subsequent activation of intracellular protein-Tyr kinase cascades.

We provide evidence for a receptor complex that acts both to mediate the adhesion of cells to $\mathrm{A} \beta$ fibrils and to activate intracellular signaling cascades. There is now extensive literature documenting the influence of cellular contacts with the extracellular matrix and other cells on the organization and coupling to intracellular signaling systems (Woods and Shimizu, 2001). These data have clearly demonstrated that the process of adhesion itself activates specific signaling pathways and also influences the efficiency of other receptors in stimulating their downstream effectors. We cannot distinguish the relative contribution of the individual receptor elements to activation of intracellular signaling pathways as distinct from those responsible for adhesion, but it seems probable that these events are intimately linked.

Microglial recognition of A $\beta$ fibrils uses a cell surface receptor complex that capitalizes on the broad substrate specificity of the individual receptor elements. We postulate that the engagement of $\mathrm{A} \beta$ fibrils with the core $\mathrm{CD} 36, \alpha_{6} \beta_{1}$, and CD47 receptors serves to bind the fibril to the cell surface, leading to immobilization and the focal aggregation of the receptors into a complex. The cooperative action of the receptor core elements confers a unique binding capability to the receptor complex that is a composite of the actions of the individual receptors. It is important to note that CD36, CD47, and $\alpha_{6} \beta_{1}$ are physically associated with Tyr kinases as well as other intracellular signaling molecules. Moreover, it has been reported that the $\alpha_{6} \beta_{1}$-integrin exists in a complex with CD36 (Thorne et al., 2000; Miao et al., 2001), and $\beta_{1}$-containing integrins have been shown to physically interact with CD47 (Wang and Frazier, 1998; Chung et al., 1999). We demonstrate a direct role of these receptors in transducing signals generated from microglial interactions with $\mathrm{A} \beta$ fibrils, resulting in the stimulation of proinflammatory pathways. The assembly of the receptor complex results in activation of Tyr kinases and downstream signaling pathways in a manner directly analogous to that of other immune receptor complexes. Importantly, disrupting the interaction of $\mathrm{A} \beta$ fibrils with any component of the receptor complex inhibits $A \beta$ stimulation of intracellular signaling cascades. The peptides interacting with the binding sites of the individual receptors do not exhibit agonist activity, suggesting that the fibrillar peptide serves to focally assemble a signaling complex. It is possible that additional cell surface receptors are involved in $\mathrm{A} \beta$ stimulation of microglial activation, either in the binding of $A \beta$ fibrils to the cell surface or the activation of intracellular signaling cascades. It is noteworthy that both CD36 and $\alpha_{6} \beta_{1}$ expression is induced on activation of myeloid-derived cells (Tontonoz et al., 1998; Kloss et al., 2001). Thus, the identification of an $\mathrm{A} \beta$-binding receptor complex provides a therapeutic intervention point, targeting the specific cell surface event resulting in the proinflammatory activation of microglia associated with $\mathrm{A} \beta$ deposits in the $\mathrm{AD}$ brain.

\section{References}

Akiyama H, Barger S, Barnum S, Bradt B, Bauer J, Cole GM, Cooper NR, Eikelenboom P, Emmerling M, Fiebich BL, Finch CE, Frautschy S, Griffin WS, Hampel H, Hull M, Landreth G, Lue L, Mrak R, Mackenzie IR, McGeer PL, O’Banion MK, Pachter J, Pasinetti G, Plata-Salaman C, Rogers J, Rydel R, Shen Y, Streit W, Strohmeyer R, Tooyoma I, Van Muiswinkel FL, Veerhuis R, Walker D, Webster S, Wegrzyniak B, Wenk G, Wyss-Coray T (2000) Inflammation and Alzheimer's disease. Neurobiol Aging 21:383-421.

Araujo DM, Cotman CW (1992) Beta-amyloid stimulates glial cells in vitro to produce growth factors that accumulate in senile plaques in Alzheimer's disease. Brain Res 569:141-145.

Babic I, Schallhorn A, Lindberg FP, Jirik FR (2000) SHPS-1 induces aggregation of $\mathrm{Ba} / \mathrm{F} 3$ pro-B cells via an interaction with $\mathrm{CD} 47$. J Immunol 164:3652-3658.

Bianca VD, Dusi S, Bianchini E, Dal Pra I, Rossi F (1999) beta-amyloid activates the $\mathrm{O}-2$ forming NADPH oxidase in microglia, monocytes, and neutrophils: a possible inflammatory mechanism of neuronal damage in Alzheimer's disease. J Biol Chem 274:15493-15499.

Boland K, Behrens M, Choi D, Manias K, Perlmutter DH (1996) The serpinenzyme complex receptor recognizes soluble, nontoxic amyloid- $\beta$ peptide but not aggregated, cytotoxic amyloid- $\beta$ peptide. J Biol Chem 271:18032-18044.

Bornstein P (1995) Diversity of function is inherent in matricellular proteins: an appraisal of thrombospondin 1. J Cell Biol 130:503-506.

Bradford MM (1976) A rapid and sensitive method for the quantitation of microgram quantities of protein utilizing the principle of protein-dye binding. Anal Biochem 72:248-254. 
Breitner JC (1996) The role of anti-inflammatory drugs in the prevention and treatment of Alzheimer's disease. Annu Rev Med 47:401-411.

Brown EJ, Frazier WA (2001) Integrin-associated protein (CD47) and its ligands. Trends Cell Biol 11:130-135.

Bull HA, Brickell PM, Dowd PM (1994) Src-related protein tyrosine kinases are physically associated with the surface antigen CD36 in human dermal microvascular endothelial cells. FEBS Lett 351:41-44.

Burdick D, Soreghan B, Kwon M, Kosmoski J, Knauer M, Henschen A, Yates J, Cotman C, Glabe C (1992) Assembly and aggregation properties of synthetic Alzheimer's A4/beta amyloid peptide analogs. J Biol Chem 267:546-554.

Chen LM, Bailey D, Fernandez-Valle C (2000) Association of beta 1 integrin with focal adhesion kinase and paxillin in differentiating Schwann cells. J Neurosci 20:3776-3784.

Chung J, Gao AG, Frazier WA (1997) Thrombospondin acts via integrinassociated protein to activate the platelet integrin alphaIIbbeta3. J Biol Chem 272:14740-14746.

Chung J, Wang XQ, Lindberg FP, Frazier WA (1999) Thrombospondin-1 acts via IAP/CD47 to synergize with collagen in alpha2betal-mediated platelet activation. Blood 94:642-648.

Combs CK, Johnson DJ, Cannady SB, Lehman TM, Landreth GE (1999) Identification of microglial signal transduction pathways mediating a neurotoxic response to amyloidogenic fragments of $\beta$-amyloid and prion proteins. J Neurosci 19:928-939.

Combs CK, Johnson DE, Karlo JC, Cannady SB, Landreth GE (2000) Inflammatory mechanisms in Alzheimer's disease: inhibition of $\beta$-amyloidstimulated proinflammatory responses and neurotoxicity by PPARgamma agonists. J Neurosci 20:558-567.

Combs CK, Karlo JC, Kao SC, Landreth GE (2001) $\beta$-Amyloid stimulation of microglia and monocytes results in TNF $\alpha$-dependent expression of inducible nitric oxide synthase and neuronal apoptosis. J Neurosci 21:1179-1188.

Coraci IS, Husemann J, Berman JW, Hulette C, Dufour JH, Campanella G, Luster AD, Silverstein SC, El Khoury J (2002) CD36, a class B scavenger receptor, is expressed on microglia in Alzheimer's disease brains and can mediate production of reactive oxygen species in response to betaamyloid fibrils. Am J Pathol 160:101-112.

Dineley KT, Westerman M, Bui D, Bell K, Ashe KH, Sweatt JD (2001) Betaamyloid activates the mitogen-activated protein kinase cascade via hippocampal $\alpha 7$ nicotinic acetylcholine receptors: in vitro and in vivo mechanisms related to Alzheimer's disease. J Neurosci 21:4125-4133.

El Khoury J, Hickman SE, Thomas CA, Cao L, Silverstein SC, Loike JD (1996) Scavenger receptor-mediated adhesion of microglia to $\beta$-amyloid fibrils. Nature 382:716-719.

Fiala M, Zhang L, Gan X, Sherry B, Taub D, Graves MC, Hama S, Way D, Weinand M, Witte M, Lorton D, Kuo YM, Roher AE (1998) Amyloidbeta induces chemokine secretion and monocyte migration across a human blood-brain barrier model. Mol Med 4:480-489.

Frazier WA, Gao AG, Dimitry J, Chung J, Brown EJ, Lindberg FP, Linder ME (1999) The thrombospondin receptor integrin-associated protein (CD47) functionally couples to heterotrimeric Gi. J Biol Chem 274:8554-8560.

Gao AG, Lindberg FP, Finn MB, Blystone SD, Brown EJ, Frazier WA (1996) Integrin-associated protein is a receptor for the C-terminal domain of thrombospondin. J Biol Chem 271:21-24.

Ghiso J, Rostagno A, Gardella JE, Liem L, Gorevic PD, Frangione B (1992) A 109-amino-acid C-terminal fragment of Alzheimer's-disease amyloid precursor protein contains a sequence, -RHDS-, that promotes cell adhesion. Biochem J 288:1053-1059.

Giulian D, Haverkamp LJ, Yu J, Karshin W, Tom D, Li J, Kazanskaia A, Kirkpatrick J, Roher AE (1998) The HHQK domain of beta-amyloid provides a structural basis for the immunopathology of Alzheimer's disease. J Biol Chem 273:29719-29726.

Hartung HP, Kladetzky RG, Melnik B, Hennerici M (1986) Stimulation of the scavenger receptor on monocytes-macrophages evokes release of arachidonic acid metabolites and reduced oxygen species. Lab Invest 55:209-216.

Hsu HY, Nicholson AC, Hajjar DP (1996) Inhibition of macrophage scavenger receptor activity by tumor necrosis factor- $\alpha$ is transcriptionally and post-transcriptionally regulated. J Biol Chem 271:7767-7773.

Huang F, Buttini M, Wyss-Coray T, McConlogue L, Kodama T, Pitas RE, Mucke L (1999) Elimination of the class A scavenger receptor does not affect amyloid plaque formation or neurodegeneration in transgenic mice expressing human amyloid protein precursors. Am J Pathol 155:1741-1747.
Huang MM, Bolen JB, Barnwell JW, Shattil SJ, Brugge JS (1991) Membrane glycoprotein IV (CD36) is physically associated with the Fyn, Lyn, and Yes protein-tyrosine kinases in human platelets. Proc Natl Acad Sci USA 88:7844-7848

Husemann J, Loike JD, Kodama T, Silverstein SC (2001) Scavenger receptor class B type I (SR-BI) mediates adhesion of neonatal murine microglia to fibrillar beta-amyloid. J Neuroimmunol 114:142-150.

in't Veld BA, Ruitenberg A, Hofman A, Stricker BH, Breteler MM (2001) Antihypertensive drugs and incidence of dementia: the Rotterdam Study. Neurobiol Aging 22:407-412.

Ishibashi Y, Claus S, Relman DA (1994) Bordetella pertussis filamentous hemagglutinin interacts with a leukocyte signal transduction complex and stimulates bacterial adherence to monocyte CR3 (CD11b/CD18). J Exp Med 180:1225-1233.

Jiang P, Lagenaur CF, Narayanan V (1999) Integrin-associated protein is a ligand for the P84 neural adhesion molecule. J Biol Chem 274:559-562.

Jimenez B, Volpert OV, Crawford SE, Febbraio M, Silverstein RL, Bouck N (2000) Signals leading to apoptosis-dependent inhibition of neovascularization by thrombospondin-1. Nat Med 6:41-48.

Klegeris A, Walker DG, McGeer PL (1994) Activation of macrophages by Alzheimer beta amyloid peptide. Biochem Biophys Res Commun 199:984-991.

Kloss CU, Bohatschek M, Kreutzberg GW, Raivich G (2001) Effect of lipopolysaccharide on the morphology and integrin immunoreactivity of ramified microglia in the mouse brain and in cell culture. Exp Neurol 168:32-46.

Krieger M, Herz J (1994) Structures and functions of multiligand lipoprotein receptors: macrophage scavenger receptors and LDL receptor-related protein (LRP). Annu Rev Biochem 63:601-637.

Le Y, Gong W, Tiffany HL, Tumanov A, Nedospasov S, Shen W, Dunlop NM, Gao JL, Murphy PM, Oppenheim JJ, Wang JM (2001) Amyloid (beta)42 activates a G-protein-coupled chemoattractant receptor, FPR-like-1. J Neurosci 21:RC123(1-5).

Lin TH, Rosales C, Mondal K, Bolen JB, Haskill S, Juliano RL (1995) Integrin-mediated tyrosine phosphorylation and cytokine message induction in monocytic cells: a possible signaling role for the Syk-tyrosine kinase. J Biol Chem 270:16189-16197.

Lorenzo A, Yankner BA (1994) Beta-amyloid neurotoxicity requires fibril formation and is inhibited by Congo red. Proc Natl Acad Sci USA 91:12243-12247.

Lorton D (1997) Beta-amyloid-induced IL-1 beta release from an activated human monocyte cell line is calcium- and G-protein-dependent. Mech Aging Dev 94:199-211.

Lorton D, Kocsis JM, King L, Madden K, Brunden KR (1996) Beta-amyloid induces increased release of interleukin-1 beta from lipopolysaccharideactivated human monocytes. J Neuroimmunol 67:21-29.

Lue LF, Walker DG, Brachova L, Beach TG, Rogers J, Schmidt AM, Stern DM, Yan SD (2001) Involvement of microglial receptor for advanced glycation end products (RAGE) in Alzheimer's disease: identification of a cellular activation mechanism. Exp Neurol 171:29-45.

Mackenzie IR, Munoz DG (1998) Nonsteroidal anti-inflammatory drug use and Alzheimer-type pathology in aging. Neurology 50:986-990.

Matter ML, Zhang Z, Nordstedt C, Ruoslahti E (1998) The alpha5betal integrin mediates elimination of amyloid-beta peptide and protects against apoptosis. J Cell Biol 141:1019-1030.

Maxeiner H, Husemann J, Thomas CA, Loike JD, El Khoury J, Silverstein SC (1998) Complementary roles for scavenger receptor A and CD36 of human monocyte-derived macrophages in adhesion to surfaces coated with oxidized low-density lipoproteins and in secretion of $\mathrm{H}_{2} \mathrm{O}_{2}$. J Exp Med 188:2257-2265.

McDonald D, Bamberger M, Combs C, Landreth G (1998) $\beta$-Amyloid fibril activate parallel mitogen-activated protein kinase pathways in microglia and THP-1 monocytes. J Neurosci 18:4451-4460.

McDonald DR, Brunden KR, Landreth GE (1997) Amyloid fibrils activate tyrosine kinase-dependent signaling and superoxide production in microglia. J Neurosci 17:2284-2294.

Meda L, Cassatella MA, Szendrei GI, Otvos L, Baron P, Villalba M, Ferrari D, Rossi F (1995) Activation of microglial cells by beta-amyloid protein and interferon-gamma. Nature 374:647-650.

Meda L, Bernasconi S, Bonaiuto C, Sozzani S, Zhou D, Otvos Jr L, Mantovani A, Rossi F, Cassatella MA (1996) Beta-amyloid (25-35) peptide and IFN-gamma synergistically induce the production of the chemotactic cy- 
tokine MCP-1/JE in monocytes and microglial cells. J Immunol 157:1213-1218.

Meda L, Baron P, Prat E, Scarpini E, Scarlato G, Cassatella MA, Rossi F (1999) Proinflammatory profile of cytokine production by human monocytes and murine microglia stimulated with beta-amyloid[25-35]. J Neuroimmunol 93:45-52.

Miao WM, Vasile E, Lane WS, Lawler J (2001) CD36 associates with CD9 and integrins on human blood platelets. Blood 97:1689-1696.

Moore KJ, El Khoury J, Medeiros LA, Terada K, Geula C, Luster AD, Freeman MW (2002) A CD36-initiated signaling cascade mediates inflammatory effects of beta-amyloid. J Biol Chem 277:49982-49988.

Murphy Jr GM, Yang L, Cordell B (1998) Macrophage colony-stimulating factor augments beta-amyloid-induced interleukin-1, interleukin-6, and nitric oxide production by microglial cells. J Biol Chem 273:20967-20971.

Paresce DM, Ghosh RN, Maxfield FR (1996) Microglial cells internalize aggregates of the Alzheimer's disease amyloid beta-protein via a scavenger receptor. Neuron 17:553-565.

Pearce SFA, Wu J, Silverstein RL (1995) Recombinant GST/CD36 fusion proteins define a thrombospondin binding domain: evidence for a single calcium-dependent binding site on CD36. J Biol Chem 270:2981-2986.

Pettit DL, Shao Z, Yakel JL (2001) $\beta$-Amyloid(1-42) peptide directly modulates nicotinic receptors in the rat hippocampal slice. J Neurosci 21:RC120(1-5).

Pick E (1986) Microassays for superoxide and hydrogen peroxide production and nitroblue tetrazolium reduction using an enzyme immunoassay microplate reader. Methods Enzymol 132:407-421.

Pike CJ, Burdick D, Walencewicz AJ, Glabe CG, Cotman CW (1993) Neurodegeneration induced by $\beta$-amyloid peptides in vitro: the role of peptide assembly state. J Neurosci 13:1676-1687.

Porter JC, Hogg N (1998) Integrins take partners: cross-talk between integrins and other membrane receptors. Trends Cell Biol 8:390-396.

Rich JB, Rasmusson DX, Folstein MF, Carson KA, Kawas C, Brandt J (1995) Nonsteroidal anti-inflammatory drugs in Alzheimer's disease. Neurology 45:51-55.

Scharnagl H, Tisljar U, Winkler K, Huttinger M, Nauck MA, Gross W, Wieland H, Ohm TG, Marz W (1999) The betaA4 amyloid peptide complexes to and enhances the uptake of beta-very low density lipoproteins by the low density lipoprotein receptor-related protein and heparan sulfate proteoglycans pathway. Lab Invest 79:1271-1286.
Stewart WF, Kawas C, Corrada M, Metter EJ (1997) Risk of Alzheimer's disease and duration of NSAID use. Neurology 48:626-632.

Terzi E, Holzemann G, Seelig J (1994) Alzheimer beta-amyloid peptide 2535: electrostatic interactions with phospholipid membranes. Biochemistry 33:7434-7441.

Thorne RF, Marshall JF, Shafren DR, Gibson PG, Hart IR, Burns GF (2000) The integrins alpha3betal and alpha6betal physically and functionally associate with CD36 in human melanoma cells: requirement for the extracellular domain OF CD36. J Biol Chem 275:35264-35275.

Tontonoz P, Nagy L, Alvarez JG, Thomazy VA, Evans RM (1998) PPARgamma promotes monocyte/macrophage differentiation and uptake of oxidized LDL. Cell 93:241-252.

Van Muiswinkel FL, Raupp SF, de Vos NM, Smits HA, Verhoef J, Eikelenboom P, Nottet HS (1999) The amino-terminus of the amyloid-beta protein is critical for the cellular binding and consequent activation of the respiratory burst of human macrophages. J Neuroimmunol 96:121-130.

Wang XQ, Frazier WA (1998) The thrombospondin receptor CD47 (IAP) modulates and associates with alpha2 betal integrin in vascular smooth muscle cells. Mol Biol Cell 9:865-874.

Wang XQ, Lindberg FP, Frazier WA (1999) Integrin-associated protein stimulates alpha2beta1-dependent chemotaxis via Gi-mediated inhibition of adenylate cyclase and extracellular-regulated kinases. J Cell Biol 147:389-400

Wong WS, Simon DI, Rosoff PM, Rao NK, Chapman HA (1996) Mechanisms of pertussis toxin-induced myelomonocytic cell adhesion: role of Mac-1(CD11b/CD18) and urokinase receptor (CD87). Immunology 88:90-97.

Wood JG, Zinsmeister P (1991) Tyrosine phosphorylation systems in Alzheimer's disease pathology. Neurosci Lett 121:12-16.

Woods ML, Shimizu Y (2001) Signaling networks regulating betal integrinmediated adhesion of T lymphocytes to extracellular matrix. J Leukoc Biol 69:874-880.

Yan SD, Chen X, Fu J, Chen M, Zhu H, Roher A, Slattery T, Zhao L, Nagashima M, Morser J, Migheli A, Nawroth P, Stern D, Schmidt AM (1996) RAGE and amyloid-beta peptide neurotoxicity in Alzheimer's disease. Nature 382:685-691.

Yates SL, Burgess LH, Kocsis-Angle J, Antal JM, Dority MD, Embury PB, Piotrkowski AM, Brunden KR (2000) Amyloid beta and amylin fibrils induce increases in proinflammatory cytokine and chemokine production by THP-1 cells and murine microglia. J Neurochem 74:1017-1025. 